\section{BURNOUT SYNDROME AND DARK \\ TRIAD AT SCHOOLS: ENGINEERS \\ AS TEACHERS OF VOCATIONAL TECHNICAL SUBJECTS}

\begin{abstract}
The aim of the present study was to verify the relationship of three aversive personality traits Machiavellianism, narcissism and psychopathy, nowadays known by experts as the Dark Triad and burnout syndrome on the sample of vocational technical subject teachers. The study was carried out on a sample of 241 participants $\left(M_{\text {age }}=44.53 ; S D=10.29\right)$. Females represented $75.1 \%$ of all respondents $\left(M_{\text {age }}=44.48 ; S D=10.02\right)$, males represented the remaining $24.9 \%$ of respondents $\left(M_{\text {age }}=42.36 ; S D=11.8\right)$. The Slovak version of Short Dark Triad-SD3 and the adapted Slovak version of Maslach Burnout Inventory - HSS on the sample of helping professionals were administered. Significant positive relations of the Dark Triad traits with emotional exhaustion, depersonalization and personal satisfaction were identified. Regression analysis indicated the Dark Triad as a significant predictor of emotional exhaustion and depersonalization, psychopathy was the most significant predictor. The Dark Triad concept predicted $58 \%$ of burnout syndrome's variance.
\end{abstract}

\section{KEYWORDS}

Burnout syndrome, Dark Triad, secondary school, vocational technical subjects teachers

\section{HOW TO CITE}

Čopková R. (2021) 'Burnout Syndrome and Dark Triad at Schools: Engineers as Teachers of Vocational Technical Subjects', Journal on Efficiency and Responsibility in Education and Science, vol. 14, no. 3, pp. 195-203. http://dx.doi.org/10.7160/eriesj.2021.140306

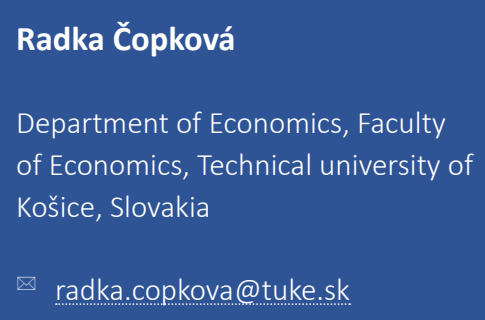

Article history

Received

February 11, 2021

Received in revised form

July 6, 2021

Accepted

August 24, 2021

Available on-line

September 30, 2021

Highlights

- Dark Triad is a significant predictor of emotional exhaustion and depersonalization.

- Dark Triad concept predicted 58\% of burnout syndrome's variance.

- Issue of courses for future teachers with practical personal development training.

\section{INTRODUCTION}

The Slovak legislation (Law Act No. 138/2019; the Act on Educational and Professional Employees and on Changes and Supplements to Some Laws) allows an individual to become a teacher in several possible ways. Usually, the teacher obtains the necessary qualification either by graduation at the second stage at the Faculty of Education in the relevant teaching field of education or, as far as teachers of vocational subjects are concerned, by graduation at the second stage of the university providing the specialization in the vocational field and additionally by obtaining the necessary pedagogical qualifications via pedagogical course. According to this law, therefore, not only a person who has completed education in Pedagogy but also an expert in another field (e.g. an engineer) who has acquired the pedagogical competencies within the additional pedagogical qualification can become a teacher.
Although this path may seem relatively simple, there are some problems with the focus of the initial teacher's education, especially if the teacher is initially a technical specialist, i.e. an engineer.

During engineering studies at the university, the student is trained primarily in the technical field. There is no reason to develop pedagogical-psychological competencies in some way. If the graduate engineers decide to complete a qualification in a pedagogical direction, they will also be in contact with the field of pedagogy, didactics, and psychology. However, given the length of qualification training ( 2 years), these topics are only marginally discussed. Table 1 presents a brief comparison of hours dedicated to psychological subjects during 2 years long pedagogical course and 5 years long university study. It is important to note that hours may vary due to a specific study programe. 


\begin{tabular}{l|c|c} 
& $\begin{array}{c}\text { Pedagogical course } \\
\text { (in hours) }\end{array}$ & $\begin{array}{c}\text { Faculty of Education } \\
\text { (in hours) }\end{array}$ \\
\hline UNIPO* $^{*}$ & 390 & 720 \\
\hline UMB $^{*}$ & 54 & 240 \\
\hline TRUNI $^{*}$ & 35 & $x$ \\
\hline TUKE $^{*}$ & 45 & $x$ \\
\hline UNIBA $^{*}$ & 240 & 330 \\
\hline
\end{tabular}

*data obtained from websites of University of Prešov (www.unipo. sk), Matej Bel University (www.umb.sk), Trnava University (www. truni.sk), Technical University of Košice (www.tuke.sk), Comenius University in Bratislava (www.uniba.sk)

Table 1: Psychological subjects - hours at the course and university studies

From a psychological point of view, the great emphasis is placed on the teacher meeting certain criteria related to his or her personality, e.g. teacher should be empathetic, fair, open, flexible, skillful in interpersonal relationships, emotionally stable, conscientious, student-centred, and resistant to workload and stress. Since engineers are not typical teachers compared to those who graduate from a university with a pedagogical focus, the teaching profession does not have to be calling for them and therefore it is more likely that the teacher becomes a person who possesses the dark sides of personality. As there is no additional space for psychological resistance training during the qualification study, the question of inclination to burnout is also raised. These questions have motivated research aimed at teachers of vocational subjects with a technical focus, their dark personality traits and its relationship to the probability of burnout.

\section{The Dark Triad and Teaching Profession}

The Dark Triad is a concept that has received still increasing attention in the last twenty years. Paulhus and Williams first came up with this concept in 2002, conceptualizing it as a phenomenon of three aversive personality traits Machiavellianism, narcissism and psychopathy at their subclinical level. It means the level of mentioned traits does not meet the diagnostic criteria of any personality disorder. On the contrary, those traits are commonly found in the normal population. The traits included in the concept of Dark Triad share certain common characteristics that are considered to be not socially desirable. Several authors (Lee and Ashton, 2005; Paulhus and Williams, 2002) identified those overlapping characteristics as like aggression, emotional coldness, selfcentered support, lack of honesty or insincerity. The most aversive dark trait is psychopathy. Subclinical psychopaths tend to be impulsive, brave, and seeking excitement. They do not feel remorse or guilt what makes them prone to hurt others without any interest in their well-being (Forsyth and O'Boyle, 2012). Machiavellians are well known for their manipulative behavior performed in order to achieve own goal regardless of others (Al Aïn et al., 2013). They crave power and success. Narcissism is typical for exaggerated self-love with the signs of high anxiety, because their self-image is fragile and vulnerable. They enjoy the feeling of importance and belief of superiority (Morf and Rhodenwalt, 2001). Some authors argue that this concept could be a reaction to the concept of well known Big Five (Oluf and Furnham, 2015), which is now a kind of so-called gold standard in personality research. When taking a closer look at the factor concepts of personality, it is possible to notice that in their interpretation there is an emphasis on adaptive personality traits, the so-called "brighter" side of personality. Oluf and Furnham (2015) described the Big Five model as such a concept. However, less attention was paid to the fact that each person, to some extent, also has maladaptive personality traits, the so-called "dark" side of personality. This above-mentioned statement is supported by several studies, where the relationship of Big Five traits with Dark Triad traits was examined in the context of discriminant validity (e.g. Egorova and Adamovich, 2019; Furnham, Richards and Paulhus, 2013; Jakobwitz and Egan, 2006; Malesza et al., 2019; Odiakosa, 2018; Paulhus and Williams, 2002).

Given that the personality structure predestines an individual to a great extent for the selection and subsequent pursuit of a certain profession, the research of the Dark Triad did not even skip the sphere of working behavior. A wide range of research has dealt with the Dark Triad of employees (Jonason, Slomski and Partyka, 2012; O'Boyle et al., 2012) as well as senior staff (Babiak, 1995; Furnham, 2010; Hogan and Hogan, 2001). In this environment, the Dark Triad has been associated with the use of manipulative techniques (Jonason, Slomski and Partyka, 2012), the desire for power (Lee et al, 2013) or counterproductive work behaviors such as employee theft, abuse of power or politics (O'Boyle et al., 2012). Specifically, Machiavellianism has been associated with abuse of power against subordinates, using manipulative techniques (Kiazad et al., 2010; Kessler et al., 2010); psychopathy with lowering the level of corporate responsibility and adversely affecting productivity (Boddy, 2010); narcissism with unethical behavior of executives and need for power (Amernic and Craig, 2010; Galperin, Bennett and Aquino, 2010; Rosenthal and Pittinsky, 2006). Obviously, those who exhibit the traits of the Dark Triad Machiavellianism, narcissism and psychopathy are more likely to seek out professions where they can more easily demonstrate their power, for example, law, economics, business or politics. In these professions, in addition to exerting power, which is typical for Machiavellianism, they can show and experience the excitement that is a characteristic of narcissism or to emotionally separate, which is typical of psychopathy. Much less attention, although we cannot claim that none, is devoted to the research of the Dark Triad in the professions where their performer is expected to possess particularly desirable social characteristics (Adams and Maykut, 2015; Bakir et al., 2003; Bratek et al., 2015; Pegrum and Pearce, 2015; Selingson, 1992), and these are helping professions.

The helping profession is the group of professions typical by the specific relationship between worker and client. The main goal of helping professionals should be reaching the wellbeing of the client in all life areas - physical, intellectual and psychological (Graf, Sator and Spranz-Forgasy, 2014). One of the helping professions is also a teaching profession. The helping aspect is proven by supporting the students' personal and educational development by helping professionals - teachers (Koprriva, 1997). Besides many other working tools that are useful in the performance of helping professionals, the helpers' personality seems to be one of 
the most important (Kopřiva, 1997). According to Kasáčová (2004), there are 3 categories of personality traits required from a good teacher - personal (self-esteem, creativity, selfworth, purposefulness, responsibility, emotional stability, patience, flexibility, tameness, optimism, conscientiousness, decisiveness, predictability); social (communicability, sociability, tolerance, acceptance of others, empathy, respect for others, friendliness, sense of humor, justice, pro sociability, tactfulness); ethical (altruism, congruency, honesty, selfsacrifice, consistency, straightness). As suggested above, much of the teacher's personality research is focused on identifying teacher's positive personality traits, with the Big Five perspective most often used (Berkovich and Eyal, 2019; Kalinnikova et al., 2018; Rohani, 2017; Tamban and Banasihan, 2017; Tan, Marsi and Furnham, 2018). As Lenkov, Rubtsova and Nizamova (2018) state, much less attention has been paid to the other side of the teacher's personality. A more comprehensive view of his personality, thus from both the bright and the dark perspective, could explain the diversity of teacher responses in the performance of their vocation. Fortunately, despite the inadequate examination of professional-specific samples in the Dark Triad, we can find some empirical evidence that does not exclude the occurrence of Machiavellianism, narcissism and psychopathy in a sample of teachers.

The study of Lenkov, Rubtsova and Nizamova (2018) examined the occurrence of the traits of the Dark Triad among pedagogues at three different levels of the educational process - kindergarten, school (primary and secondary) and university level. The authors obtained interesting results about school (primary and secondary) teachers who scored significantly higher in psychopathy than kindergarten teachers and university teachers. The next useful result for educational management is the significantly highest value of Machiavellianism in the sample of university teachers compared to kindergarten and school teachers. Kalinnikova et al. (2018) focused on the negative personality characteristics of secondary school teachers in the context of self-monitoring, stating that teachers with a high level of Machiavellianism are more adapted to the rules in modern secondary schools and are oriented towards the management requirements of these schools, compared to teachers from ordinary schools who are more oriented towards quality teaching of their subjects. Teacher's narcissism, in turn, results in a decline in the quality of teaching and the organization of educational processes, leading to a decrease in the academic motivation of students. Bańka and Orlowski (2012) focused their attention on one of three aversive traits of the Dark Triad - the teacher's Machiavellianism. They tried to explain the mechanism of its functioning by personality factors - self-efficacy, disposition to gratitude, values, personal resources, professional burnout syndrome; and contextual factors - organizational culture, attitude to work, duration of employment and specialization. The dominant position of Machiavellianism as a significant dark trait in teachers was also confirmed by another study in which teachers and students (future teachers) were compared in the Dark Triad components, Machiavellianism being the most dominant trait of the Dark Triad in both samples, but students scored significantly higher than teachers (Čopková, 2020).

\section{Burnout Syndrome and Teaching Profession}

Burnout syndrome is a phenomenon that, unlike the Dark Triad, is explicitly linked to work performance, although some authors (Barnett and Flores, 2016) point out that since both work and school are places where some pressure is put on individuals, burnout can also occur within students. Burnout is defined as the psychological syndrome of emotional exhaustion, depersonalization and reduced personal accomplishment, that occurs mainly among workers who encounter other people at work (Maslach, Jackson and Leiter, 1986). Over time, however, some reports have emerged that today it is no longer a phenomenon typical for helping professions, but also occurs in other professions. Therefore, the revised version of the definition of burnout syndrome refers to symptoms in the context of unsolvable work stress (Maslach, Schaufeli and Leiter, 2001). Emotional exhaustion is the most important symptom of burnout syndrome and is related to the feeling of exhaustion of one's emotional energy, predicting most of the health consequences caused by stress. Depersonalization is seen as a dysfunctional way to deal with emotional exhaustion, which means emotional cutting off from work. The reduced personal accomplishment from work refers to a negative assessment of one's work performance and the overall value of work (Maslach and Leiter, 2010; Maslach et al., 2001).

Nowadays, the teaching profession is considered to be one of the riskiest in terms of developing burnout (Schaufeli, Leiter and Maslach, 2008). In this context, Sears, Urizar and Evans (2000) speak of the syndrome that affects physical, academic, and social performance in teaching that emerges in response to a long-term stressful working conditions. Reduced teacher performance results in reduced interest in their students, colleagues, and parents of students, leaving a negative impression on the people they come in contact with (Baran et al., 2010). Van Horn, Schaufeli and Enzmann (1999) specifically highlighted the issue of burnout in high school teachers and described it as a serious occupational hazard. Travers and Cooper (1993) point out that teachers' stress levels were significantly higher than the average stress levels of other professionals in the helping professions.

The key variables that are considered to support the developing of burnout symptoms in teachers tend to be grouped into two categories - personality and contextual. Personality variables have been discussed in several studies and have included personality traits, perceived self-efficacy, existential fulfillment, constructive thinking, engagement, age, gender, length of practice, motivation to learn, willingness to work, abilities (Baran et al., 2010; Loonstra, Brouwers and Tomic, 2009). Aloe et al. (2014) summarized the findings on the length of practice and the grade at which the teacher teaches, pointing out that younger teachers tend to experience a higher degree of burnout than older colleagues, as well as high school teachers compared to those teaching in primary schools. Contextual factors include the educational system, the quality of the educational institution, workload, 
school equipment, time pressure, working conditions, lack of recognition, legislative changes, social support, relationships between colleagues, student learning problems, large classes, etc. (Aloe et al., 2014; Baran et al., 2010; Fiorilli et al., 2015; Loonstra et al., 2009). The development of teacher burnout syndrome may result in absences that directly affect the academic performance of students, increased punishing of students or disinterest in them (Aloe et al., 2014).

\section{The Dark Triad and Burnout Syndrome}

The mentioned information suggests that personality characteristics are one of the key factors influencing the development of burnout syndrome, for which due attention has been given. As expected, the studies most commonly encountered verifying the relationship of burnout with the five components of the Big Five model - emotional stability, extraversion, openness, agreeableness and conscientiousness (Anvari, Kalali and Gholipour, 2011; Bakker et al., 2006; Magnano, Paolillo and Barrano, 2015; Rothmann and Storm, 2003). Much less attention has raised the question to what extent the dark side of the personality can contribute to the development of burnout. Some studies have addressed this relationship but in a separated manner, that is, they were interested in the relationship of burnout and one of the three aversive traits of personality - Machiavellianism, narcissism and psychopathy. Mirkovic and Bianchi (2019) focused on Machiavellianism, which in their studies had a positive relationship with all three components of burnout syndrome - depersonalization, emotional exhaustion and personal accomplishment, which was mainly determined by depersonalization. Barnett and Flores (2016) focused on narcissism and burnout at school, showing a positive relationship between dark traits and burnout determined by self-pity. Schwarzkopf et al. (2016) also looked at narcissism, which in their research explained the variation of emotional exhaustion and depersonalization. Prusik and Szulawski (2019) tested the relationship of the whole dark triad with burnout and work motivation. Machiavellianism and psychopathy correlated positively with emotional exhaustion and depersonalization, and these relationships were determined by the motivational resources that led respondents to performance of the job.

The above-mentioned information shows that the relationship between burnout syndrome and Big Five personality traits has been previously examined in several studies. It follows that there is still little information on the nature of the relationship between burnout syndrome and Dark Triad what is the model that gets more and more attention in recent years. In addition, there is a lack of empirical studies working in this regard with a professional-specific sample. As we have found support in previous researches, we have decided to conduct our study on a sample of secondary school teachers of vocational technical subjects who attended only pedagogical course, not the university studies in pedagogy and were supposed to receive less psychological preparation for their future work. We aimed to test the relationship between the Dark Triad traits and burnout syndrome components in this context.

\section{MATERIALS AND METHODS}

\section{Sample}

The research sample consisted of 241 teachers of vocational technical subjects at Slovak secondary vocational schools. All participants got engineer university degree at the university with technical specialization in the past. Their age ranged from 26 to 62 years $\left(M_{\text {age }}=44.53 ; \mathrm{SD}=10.29\right)$. Females accounted for $75.1 \%$ of all respondents $(N=181)$, aged 26 to 58 years $\left(M_{\text {age }}=44.48 ; \mathrm{SD}=10.02\right)$. Males represented the remaining $24.9 \%$ of respondents $(N=60)$, aged 26 to 62 years $\left(M_{\text {age }}=\right.$ 42.36; SD = 11.8). The length of respondents' pedagogical experience ranged from 1 year to 35 years. Convenience and purposive sampling methods have been used.

\section{Tools}

Short Dark Triad (Jones and Paulhus, 2014; for Slovak version see Čopková and Šafár, 2021). Three subscales, each consisting of nine items evaluated on a 5-point Likert scale (1 = strongly disagree; $5=$ strongly agree), saturate the scale: (1) Machiavellianism $\alpha_{m}=0.692$ ("I like to use clever manipulation to get my way."), (2) narcissism $\alpha_{n}=0.487$ ("I know that I am special because everyone keeps telling me so.") (3) psychopathy $\alpha_{p}=0.758$ ("Payback needs to be quick and nasty."). There are five reverse-coded items in the questionnaire, which must be reversed before calculating the final score.

Maslach Burnout Inventory - HSS (Ráczová and Köverová, 2020). The questionnaire is an adapted Slovak version based on the original MBI - Human Services Survey (Maslach and Jackson, 1981). It consists of 22 items that saturate the three subscales - depersonalization - DP (5 items - "My work exhausts me emotionally.”), personal accomplishment - PA (8 items "I feel I have a positive effect on other people's lives through my work.") and emotional exhaustion - EE (9 items - "I'm afraid my work makes me emotionally cool."). The respondent sign answers on a 7-point scale ( 0 - never; $1=$ several times a year; 3 = once a month or less; $3=$ several times a month; $4=$ once a week; $5=$ several times a week; $6=$ daily) indicates the frequency of occurrence of the symptoms formulated in each item. Items in the personal accomplishment subscale are reverse-coded. The final score is calculated as the sum of the points marked by the respondent for each subscale separately. The indicators of the internal consistency of the scales expressed by the Cronbach alpha coefficient were as follows $\alpha_{e e}=0.876 ; \alpha_{p a}=0.731 ; \alpha_{d p}=0.726$.

\section{Procedure}

Data collection was carried out from March 2019 to April 2019 via an electronic form (Google Docs Form). First, respondents were informed that completing the questionnaire is voluntary and anonymous and that the data will only be processed within the context of this research.

All respondents agreed to participate. The collected data were analyzed in two statistical software: IBM SPSS Statistics (version 21) and IBM Amos (version 23). There were no missing data in the dataset. For testing the normality of data distribution we have used Kolmogorov-Smirnov. The data were normally distributed $(p<0.05)$. The value of the skewness and kurtosis did not exceed the criterion $> \pm 1$, which supported the 
assumption of normal distribution. The internal consistency was measured by Cronbach's $\alpha$. The obtained data were described using other descriptive indicators (mean, standard deviation). Pearson correlation coefficient was used to test the occurrence and significance of relationships between variables; complex relationships between variables were tested by multiple linear regression and structural equation modeling.

\section{RESULTS}

In the first step of the analysis, we tried to answer the question about the relationship between the Dark Triad traits and the factors of burnout on the sample of teachers teaching vocational technical subjects. The correlation analysis revealed several significant relationships. The exact values of the correlation coefficients are in Table 2.

\begin{tabular}{l|c|c|c|c|c|c|c} 
& M & SD & MACH & NAR & PSY & EE & DP \\
\hline MACH & 26.30 & 6.32 & - & & & \\
\hline NAR & 26.00 & 5.40 & $0.558^{* *}$ & - & & \\
\hline PSY & 19.90 & 7.80 & $0.649^{* *}$ & $0.569^{* *}$ & - & & \\
\hline EE & 21.10 & 10.7 & $0.319^{* *}$ & $0.245^{* *}$ & $0.387^{* *}$ & - & - \\
\hline DP & 5.02 & 4.75 & $0.332^{* *}$ & $0.267^{* *}$ & $0.484^{* *}$ & $0.549^{* *}$ & $-0.265^{* *}$ \\
\hline
\end{tabular}

$M A C H=$ Machiavellianism; $N A R=$ narcissism; $P S Y=$ psychopathy; $E E=$ emotional exhaustion; $D P=$ depersonalisation; $P A=$ personal accomplishment; $M=$ mean; $S D=$ standard deviation; ${ }^{*} p<0.05 ;{ }^{* *} p<0.01$

Table 2: Correlation matrix of SD3 and MBI-HSS

Significant positive relationships were identified in the case of Machiavellianism with emotional exhaustion and depersonalization, on the contrary, a very weak and insignificant relationship occurred between Machiavellianism and personal accomplishment. In the case of narcissism, significant positive relationships with all three components of burnout were identified - depersonalization, emotional exhaustion, and personal accomplishment. Psychopathy, same as Machiavellianism, significantly positively correlated with emotional exhaustion and depersonalization, and had a weak and insignificant relationship with personal accomplishment. Another question we have tried to answer is to what extent we can consider the individual components of the Dark Triad as predictors that explain the variability of burnout syndrome factors. Therefore, we tested the data by multiple linear regression, where the basic model was made up of three independent variables - Machiavellianism, narcissism and psychopathy, and all the factors of burnout syndrome were replaced in the role of the dependent variable step by step. The results of multiple regression analysis suggested
2 significant models. The Dark Triad explained $15.7 \%$ of the emotional exhaustion variability $(F(3 / 240)=14.751$; $\left.p<0.001 ; R^{2}=0.157\right)$, the psychopathy has explained $4.9 \%$ $(\beta=0.309 ; t=3.719 ; p<0.001)$. Furthermore, the Dark Triad explained the $23.5 \%$ variability of the depersonalization factor $\left(F(3 / 240)=24.261 ; p<0.001 ; R^{2}=0.235\right)$, psychopathy has explained $11.5 \%(\beta=0.472 ; t=5.973 ; p<0.001)$. As far as the personal accomplishment factor is concerned, the Dark Triad was not confirmed as a significant predictor $(F(3 / 240)=.716$; $\left.p=0.164 ; R^{2}=0.021\right)$, we can add that from this low percentage $(2.1 \%)$ narcissism has explained $1.9 \%$.

The above results led us to the idea of testing the acquired data more comprehensively. By analyzing the relationship between the Dark Triad and burnout syndrome, we tried to answer the question to what extent the Dark Triad traits contribute to the presence and intensity of the symptoms of burnout. By structural equation modeling, we tested a hypothetical model, model fit indicators showed acceptable values (Table 3 ).

According to the test model, the Dark Triad traits explained $58 \%\left(R^{2}=0.580\right)$ of the variation of burnout syndrome

\begin{tabular}{c|c|c|c|c|c|c|c|c|c} 
& $\boldsymbol{N}$ & $\boldsymbol{\chi}^{2}$ & df & $\boldsymbol{p}$ & $\chi^{2} / d f$ & CFI & TLI & RMSEA & SRMR \\
\hline Test model & 241 & 30.794 & 8 & $<0.001$ & 3.849 & 0.947 & 0.900 & 0.109 & 0.077 \\
\hline
\end{tabular}

Table 3: Model Fit $(N=241)$

factors in secondary school teachers of vocational technical Figure 1 presents a test model with standardized parameter subjects, which we consider as satisfactory result. The estimates.

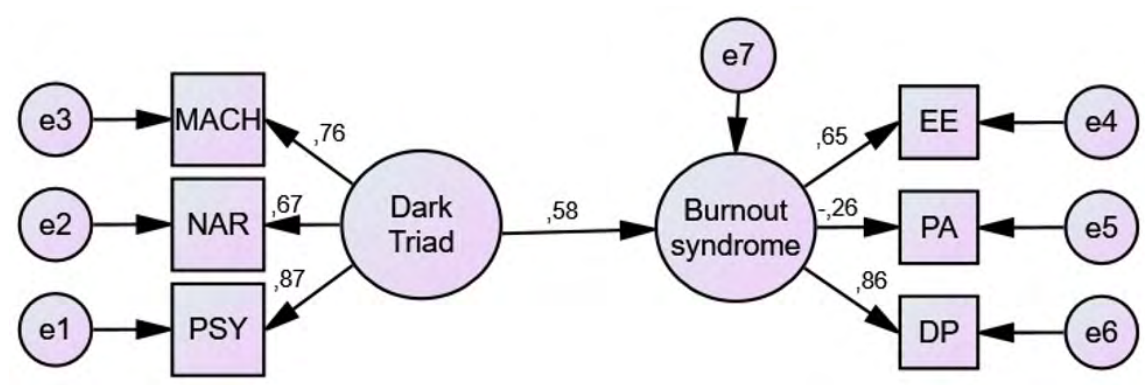

$M A C H=$ Machiavellianism; $N A R=$ arcissism; $P S Y=p s y c h o p a t h y ; E E=$ emotional exhaustion; $D P=$ depersonalisation; $P A=$ personal accomplishment

Figure 1: Tested model - standardized estimates, 2020 


\section{DISCUSSION}

Since the relationship of burnout syndrome and personality traits, especially the Big Five model, was previously examined in several studies (e.g. Anvari, Kalali and Gholipour, 2011; Bakker et al., 2006; Magnano, Paolillo and Barrano, 2015; Rothmann and Storm, 2003), the primary aim of the presented study was to examine the relationship between another personality model - Dark Triad (Machiavellianism, narcissism and psychopathy), and the components defining burnout syndrome (emotional exhaustion, depersonalization, and personal accomplishment) on a sample of secondary school teachers teaching vocational technical subjects. We were brought to this by the fact that while burnout syndrome has been extensively studied in the context of the "bright" personality traits (Anvari, Kalali and Gholipour, 2011; Bakker et al., 2006; Magnano, Paolillo and Barrano, 2015; Storm and Rothmann, 2003), much less attention has been paid to the extent to which the "dark" personality traits are involved in the development of burnout (Bańka and Orlowski, 2012; Prusik and Szulawski, 2019; Schwarzkopf et al., 2016). The selection of a specific sample on which our study was conducted - secondary school teachers of vocational technical subjects - also has its merit. The teaching profession is considered to be one of the riskiest in terms of the development of burnout (Schaufeli, Leiter and Maslach, 2008). The stress level of teachers is reported to be significantly higher than the average stress levels of workers in other helping professions (Travers and Cooper, 1993). Several authors even point out that secondary school teachers are more prone to burnout, compared to university teachers or those who teach at elementary schools (Aloe et al., 2014; Van Horn et al., 1999).

The results suggest that there are significant positive relationships between the Dark Triad and burnout. Specifically, the higher the level of Machiavellianism and psychopathy is, the greater the likelihood of developing emotional exhaustion and depersonalization is. This result partly correlates with that of Mirkovic and Bianchi (2019). Their study identified a positive relationship between Machiavellianism and all three components of burnout. We also find support in the results of Prusik and Szulawski (2019), who came to the same result as we did. The relationship between narcissism and burnout syndrome components was richer, suggesting that a higher level of narcissism is associated with a higher level of emotional exhaustion, depersonalization, and personal accomplishment. Our outcome is supported by the results of Barnett and Flores (2016), who have identified positive relationships of narcissism with all components of burnout. In Schwarzkopf et al. (2016), narcissism correlated positively with emotional exhaustion and depersonalization. The regression analysis has shown that the Dark Triad significantly predicts the development of emotional exhaustion at a rate of $15.7 \%$ and depersonalization at a rate of $23.5 \%$, psychopathy was the most important predictor in both cases. This result is not surprising when looking at the research of Lenkov et al. (2018), which points to a significant level of psychopathy among secondary school teachers compared to elementary and secondary school teachers. More comprehensive testing of Dark Triad-burnout syndrome relationship suggests that up to $58 \%$ of burnout syndrome can be explained by the presence of aversive personality traits. This result supports the idea of continuing research and expanding the research portfolio to address the relationships and the broader context of these negative phenomena.

In the future, the question arises as to whether it would be worthy to incorporate the Big Five concept into the model and to look in more detail at what personality traits, both dark and bright, are involved in the development of the symptoms of burnout. Our study is considerably limited by the fact that its results can be generalized only to a limited extent, as it was carried out on a narrow profile sample of secondary school teachers of vocational subjects with a technical focus. Therefore, we consider it beneficial if in the future the research of the Dark Triad and burnout syndrome would be aimed at comparing teachers at different levels - elementary, secondary and higher, as several studies suggest that there should be differences between them as in personality (Bańka and Orlowski, 2012; Kalinnikova et al., 2018; Lenkov, Rubtsova and Nizamova, 2018) as well as at the risk of developing burnout syndrome (Aloe et al., 2014). Several studies (Aloe et al., 2014; Baran et al., 2010; Barnett and Flores, 2016; Fiorili et al., 2015; Loonstra et al., 2009; Prusik and Sulawski, 2019) have already proposed the possibility to consider other mediation variables in relation to the Dark Triad and burnout syndrome. In our opinion, there should be variables such as job satisfaction (Čopková and Araňošová, 2020), career motivation (McLean, Taylor and Jimenez, 2019), experiencing crisis in achieving goals (Bavolár and Kačmár, 2020), coping (Vavricová, 2013), leadership styles (Arnold et al., 2015), self-efficacy (Skaalvik and Skaalvik, 2010), self-care (Lichner, 2017) or length of practice considered as the potential mediators of this relationship. It might also be interesting to compare teachers of vocational subjects with technical and non-technical focus.

\section{CONCLUSION}

The present study aimed to examine the relationship between burnout syndrome and personality model popular in recent years - the Dark Triad. The uniqueness of the study results from the specific sample - teachers of vocational technical subjects who are not considered as common teachers in Slovakia. Teachers as helping professionals are more prone to burnout syndrome development. On the other hand, the teaching profession offers the environment for negative personality traits demonstration as well. The present study showed that psychopathy is the significant predictor of emotional exhaustion and depersonalization. Moreover, dark traits (Machiavellianism, narcissism, psychopathy) explained the majority of burnout syndrome occurrence what is considered to be the most important finding.

Due to results obtained in the research, our study shows the necessity of paying more attention to the personalities of teachers who have not been trained as common teachers, since teachers are the people who influence students not only at the professional but also at the affective level. The negative effect of teachers' personality might be prevented or avoided by including the personality assessments in recruitment interviews for novices at universities or organizations providing pedagogical courses, but at the schools as employing institutions as well. 
Therefore, it is necessary to consider extending courses for future teachers with practical personal development training as a compulsory part of the curriculum. As a part of long-life development, we suggest the implementation of personality development soft skills training for teachers at all levels of educational system. It could be the way how to teach teachers the principles of self-regulation what includes standards of desirable behavior, motivation to meet standards, monitoring of situations and thoughts and willpower (Baumeister, Heatherton and Tice, 1994; Čopková, 2020), not excluding the resistance to stress development by adoption of basic psychohygiene principles (Kusý and Báthoryová, 2013). Sure, the personality structure can not be fully changed, but the training is at least the opportunity how to learn how to suppress the performance of negative traits and strengthen the desirable outcomes.

\section{REFERENCES}

Adams, L. Y. and Maykut, C. A. (2015) 'Bullying: The antithesis of caring acknowledging the dark side of the nursing profession', International Journal of Caring Sciences, Vol. 8, No. 3, pp. 765-773.

Al Aïn, S., Carré, A., Fantini-Hauwel, C., Baudouin, J. Y. and Besche-Richard, C. (2013) 'What is the emotional core of the multidimensional Machiavellian personality trait?', Frontiers in Psychology, Vol. 4, 454, pp. 1-8. https://doi.org/10.3389/ fpsyg.2013.00454

Aloe, A. M., Shisler, S. M., Norris, B. D., Nickerson, A. B. and Rinker, T. W. (2014) 'A multivariate meta-analysis of student misbehavior and teacher burnout', Educational Research Review, Vol. 12, pp. 30-44. https://doi.org/10.1016/j.edurev.2014.05.003

Amernic, J. H. and Craig, R. J. (2010) 'Accounting as a facilitator of extreme narcissism', Journal of business ethics, Vol. 96, No.1, pp. 79-93. https://doi.org/10.1007/s10551-010-0450-0

Anvari, M. R. A., Kalali, N. S. and Gholipour, A. (2011) 'How does personality affect on job burnout?', International Journal of Trade, Economics and Finance, Vol. 2, No. 2, pp. 115-119.

Arnold, K. A., Connelly, C. E., Walsh, M. M. and Martin Ginis, K. A. (2015) 'Leadership styles, emotion regulation, and burnout', Journal of Occupational Health Psychology, Vol. 20, No. 4, pp. 481-490. https://doi.org/10.1037/a0039045

Babiak, P. (1995) 'When psychopaths go to work: A case study of an industrial psychopath', Applied Psychology, Vol. 44, No. 2, pp. 171-188. https://doi.org/10.1111/j.1464-0597.1995.tb01073.x

Bakir, B., Özer, M., Uçar, M., Güleç, M., Demir, C. and Hasde, M. (2003) 'Relation between Machiavellianism and job satisfaction in a sample of Turkish physicians', Psychological reports, Vol. 92, No. 3, pp. 1169-1175. https://doi.org/10.2466/ pr0.2003.92.3c.1169

Bakker, A. B., Van Der Zee, K. I., Lewig, K. A. and Dollard, M. F. (2006) 'The relationship between the big five personality factors and burnout: A study among volunteer counselors', The Journal of social psychology, Vol. 146, No.1, pp. 31-50. https://doi. org/10.3200/SOCP.146.1.31-50

Bańka, A. and Orłowski, K. (2012) 'The structure of the teacher Machiavellianism model in social interactions in a school environment', Polish Psychological Bulletin, Vol. 43, No. 4, pp. 215-222. https://doi.org/10.2478/v10059-012-0024-3

Baran, G., Bıçakçı, M. Y., İnci, F., Öngör, M., Ceran, A. and Atar, G. (2010) 'Analysis of burnout levels of teacher', ProcediaSocial and Behavioral Sciences, Vol. 9, pp. 975-980. https://doi. org/10.1016/j.sbspro.2010.12.270

Barnett, M. D. and Flores, J. (2016) 'Narcissus, exhausted: Selfcompassion mediates the relationship between narcissism and school burnout', Personality and Individual Differences, Vol. 97, pp. 102-108. https://doi.org/10.1016/j.paid.2016.03.026
Baumeister, R. F., Heatherton, T. F. and Tice, D. M. (1994) Losing control: How and why people fail at self-regulation, San Diego, CA: Academic Press.

Bavolár, J. and Kačmár, P. (2020) 'Pracovné ciele u pracujúcich', Proceedings of the 19th international conference Work and Organizational Psychology 2020, Košice: Institute of Social Sciences, CSPS SAS, pp. 96-106. https://doi. org/10.31577/2020.978-80-89524-51-8.8

Berkovich, I. and Eyal, O. (2019) 'Teachers' Big Five personality traits, emotion regulation patterns, and moods: mediation and prototype analyses', Research Papers in Education, Vol. 36, No. 3, pp. 1-23. https://doi.org/10.1080/02671522.2019.1677758

Boddy, C. R. P. (2010) 'Corporate psychopaths and organizational type', Journal of Public Affairs, Vol. 10, No. 4, pp. 300-312. https://doi.org/10.1002/pa.365

Bratek, A., Bonk, M., Bulska, W., Tyrała, K., Seweryn, M. and Krysta, K. (2015) "“ claw your way"- Machiavellianism among the medical community', Psychiatria Danubina, Vol. 27, No.1, pp. 344-347.

Čopková, R. (2020) 'The Dark Triad in Helping Professions Comparison of Teachers and Pedagogy Students', Journal of Women's Entrepreneurship and Education, No.1-2, pp. 125-141. https://doi.org/10.28934/jwee20.12.pp125-141

Čopková, R. and Araňošová, A. (2020) 'The Relationship of Dark Triad and Job Satisfaction among Helping Professionals', Človek a spoločnost', Vol. 23, No. 3, pp. 18-33. http://doi.org/10.31577/ cas.2020.03.574

Čopková, R. and Šafár, L. (2021) 'Psychomeric Properties of the Slovak Version of Short Dark Triad (SD3)', European Journal of Investigation in Health, Psychology and Education, Vol. 11, No. 3, pp. 649 - 666. https://doi.org/10.3390/ejihpe11030047

Egorova, M. S. and Adamovich, T. V. (2019) 'Factor Structure of The Short Dark Triad (SD3) in Adolescents', The European Proceedings of Social \& Behavioral Sciences, Vol. 64, pp. 130137. https://doi.org/10.15405/epsbs.2019.07.17

Fiorilli, C., Gabola, P., Pepe, A., Meylan, N., Curchod-Ruedi, D., Albanese, O. and Doudin, P. A. (2015) 'The effect of teachers' emotional intensity and social support on burnout syndrome. A comparison between Italy and Switzerland', Revue Européenne de Psychologie Appliquée/European Review of Applied Psychology, Vol. 65, No. 6, pp. 275-283. https://doi. org/10.1016/j.erap.2015.10.003

Forsyth, D. R. and O'Boyle, E. H., Jr. (2012) 'Ethics position theory and unethical work behavior', in R. A. Giacalone and M. D. Promislo (ed.), Handbook of unethical work behavior: Implications for individual well-being (pp. 221-236), New York: M.E. Sharpe. 
Furnham, A. (2010) The Elephant in the Boardroom: The Causes of Leadership Derailment. Basingstoke: Palgrave MacMillan.

Furnham, A., Richards, S. C. and Paulhus, D. L. (2013) 'The Dark Triad of personality: A 10 year review', Social and Personality Psychology Compass, Vol. 7, No. 3, pp. 199-216. https://doi. org $/ 10.1111 / \mathrm{spc} 3.12018$

Galperin, B. L., Bennett, R. J. and Aquino, K. (2011) 'Status differentiation and the protean self: A social-cognitive model of unethical behavior in organizations', Journal of Business Ethics, Vol. 98, No. 3, pp. 407-424. https://doi.org/10.1007/s10551-010$\underline{0556-4}$

Graf, E. M., Sator, M. and Spranz-Fogasy, T. (ed.) (2014) Discourses of helping professions, (Vol. 252), Amsterdam: John Benjamins Publishing Company. https://doi.org/10.1075/pbns.252

Hogan, R. and Hogan, J. (2001) 'Assessing leadership: A view from the dark side', International Journal of Selection and Assessment, Vol. 9, No. 1-2, pp. 40-51. https://doi.org/10.1111/1468-2389.00162

Jakobwitz, S. and Egan, V. (2006) 'The Dark Triad and normal personality traits', Personality and Individual differences, Vol. 40, No. 2, pp. 331-339. https://doi.org/10.1016/j.paid.2005.07.006

Jonason, P. K., Slomski, S. and Partyka, J. (2012) 'The Dark Triad at work: How toxic employees get their way', Personality and individual differences, Vol. 52, No. 3, pp. 449-453. https://doi. org/10.1016/j.paid.2011.11.008

Kalinnikova, L., Saplavska, J., Zavodilov, A. and Rimkus, O. (2018) 'Negative personality traits and self-monitoring among high school teachers', Proceedings of International conference "Engineering for Rural Development", Jelgava, pp. 1129-1135.

Kasáčová, B. (2004) Učitel'ská profesia v trendoch teórie a praxe, Prešov: Metodicko-pedagogické centrum.

Kessler, S. R., Bandell, A. C., Spector, P. E., Borman, W. C., Nelson, C. E. and Penney, L. M. (2010) 'Re-examining Machiavelli: A three-dimensional model of Machiavellianism in the workplace', Journal of Applied Social Psychology, Vol. 40, No. 8, pp. 18681896. https://doi.org/10.1111/j.1559-1816.2010.00643.x

Kiazad, K., Restubog, S. L. D., Zagenczyk, T. J., Kiewitz, C. and Tang, R. L. (2010) 'In pursuit of power: The role of authoritarian leadership in the relationship between supervisors' Machiavellianism and subordinates' perceptions of abusive supervisory behavior', Journal of Research in Personality, Vol. 44, No. 4, pp. 512-519. https://doi.org/10.1016/j.jrp.2010.06.004

Kopřiva, K. (1997) Lidský vztah mezi pracovnikem a klientem. Lidský vztah jako součast profese [The human relationship between the professional and the client. Human relationship as part of the helping profession], $2^{\text {nd }}$ edition, Prague: Portál.

Kusý, P. and Báthoryová, D. (2013) 'Potreba psychohygieny v pedagogických profesiách' [The need for psychohygiene in pedagogical professions], Výzvy a inšpirácie $v$ pedagogických vedách: Zborník príspevkov z X. medzinárodnej konferencie doktorandov, Nitra, pp. 198-204.

Law Act No. 138/2019; the Act on Educational and Professional Employees and on Changes and Supplements to Some Laws (2019), [Online], Available: https://www.minedu.sk/data/att/15401.pdf [10 Apr 2020]

Lee, K. and Ashton, M. C. (2014) 'The dark triad, the big five, and the HEXACO model', Personality and Individual Differences, Vol. 67, pp. 2-5. https://doi.org/10.1016/j.paid.2014.01.048

Lee, K., Ashton, M. C., Wiltshire, J., Bourdage, J. S., Visser, B. A. and Gallucci, A. (2013) 'Sex, power, and money: Prediction from the dark triad and honesty-humility', European Journal of Personality, Vol. 27, No. 2, pp. 169-184. https://doi.org/10.1002/per.1860
Lenkov, S. L., Rubtsova, N. E. and Nizamova, E. S. (2018) 'The Dark Triad Of Personality In Kindergarten, School And University Teachers', ICPE 2018-International Conference on Psychology and Education, Moscow, pp. 352-367. https://doi.org/10.15405/ epsbs(2357-1330).2018.11.2

Lichner, V. (2017) 'Performed self-care in the context of resisting negative workplace consequences among Slovak social professionals', Canadian International Journal of Social Science and Education, Vol. 13, No. 1, pp. 312-320.

Loonstra, B., Brouwers, A. and Tomic, W. (2009) 'Feelings of existential fulfilment and burnout among secondary school teachers', Teaching and Teacher Education, Vol. 25, No. 5, pp. 752-757. https://doi. org/10.1016/j.tate.2009.01.002

Magnano, P., Paolillo, A. and Barrano, C. (2015) 'Relationships between personality and burn-out: an empirical study with helping professions' workers', International Journal of Humanities and Social Science Research, No. 1, pp. 10-19. https://doi. org/10.6000/2371-1655.2015.01.02

Maslach, C. and Leiter, M. P. (2010) 'Burnout', in Fink, G. (ed.). Stress consequences: Mental, neuropsychological and socioeconomic (pp. 726-729). New York, NY: Academic Press.

Maslach, C., Jackson, S. E., Leiter, M. P., Schaufeli, W. B. and Schwab, R. L. (1986) Maslach burnout inventory (Vol. 21, pp. 3463-3464), Palo Alto, CA: Consulting psychologists press.

Maslach, C., Schaufeli, W. B. and Leiter, M. P. (2001) 'Job burnout', Annual review of psychology, Vol. 52, No. 1, pp. 397-422. https:// doi.org/10.1146/annurev.psych.52.1.397

Malesza, M., Ostaszewski, P., Büchner, S. and Kaczmarek, M. C. (2019) 'The adaptation of the Short Dark Triad personality measurepsychometric properties of a German sample', Current Psychology, Vol. 38, No. 3, pp. 855-864. https://doi.org/10.1007/s12144-0179662-0

McLean, L., Taylor, M. and Jimenez, M. (2019) 'Career choice motivations in teacher training as predictors of burnout and career optimism in the first year of teaching', Teaching and Teacher Education, Vol. 85, No. 1, pp. 204-214. https://doi.org/10.1016/j. tate.2019.06.020

Mirkovic, D. and Bianchi, R. (2019) 'An exploratory study of the link between Machiavellianism and burnout', Personality and Individual Differences, Vol. 148, pp. 27-31. https://doi.org/10.1016/j. paid.2019.05.024

Morf, C. C. and Rhodenwalt, F. (2001) 'Unraveling the paradoxes of narcissism: A dynamic self-regulatory processing model', Psychological Inquiry, Vol. 12, No. 4, pp. 177-196. https://doi. org/10.1207/S15327965PLI1204_1

O’Boyle, E. H., Jr., Forsyth, D. R., Banks, G. C., and McDaniel, M. A. (2012) 'A meta-analysis of the Dark Triad and work behavior: A social exchange perspective', Journal of Applied Psychology, Vol. 97, No. 3, pp. 557-579. https://doi.org/10.1037/a0025679

Odiakosa, T. (2018) Examining Associations between the Dark Triad and the Big Five Personality Traits, [Online], Available: https://www. researchgate.net/publication/337889195 Examining Associations between the Dark Triad and the Big_Five Personality Traits [21 Jan 2020]

Oluf, G.-A. and Furnham, A. (2015) 'The relationship between bright-and dark-side personality traits', Personality and Individual Differences, Vol. 87, pp. 206-211. https://doi.org/10.1016/j.paid.2015.08.002

Paulhus, D. L. and Williams, K. M. (2002) 'The dark triad of personality: Narcissism, Machiavellianism, and psychopathy', Journal of Research in Personality, Vol. 36, No. 6, pp. 556-563. https://doi. org/10.1016/S0092-6566(02)00505-6 
Pegrum, J. and Pearce, O. (2015) 'A stressful job: are surgeons psychopaths?', The Bulletin of the Royal College of Surgeons of England, Vol. 97, No. 8, pp. 331-334. https://doi.org/10.1308/ rcsbull.2015.331

Prusik, M. and Szulawski, M. (2019) "The relationship between the Dark Triad personality traits, motivation at work, and burnout among HR recruitment workers', Frontiers in psychology, Vol 10, 1290. https://doi.org/10.3389/fpsyg.2019.01290

Ráczová, B. and Köverová, M. (2020) 'A confirmatory factor analysis of the Slovak version of the MBI-HSS for helping professions', Československá psychologie, Vol. 64, No .3, pp. 272-287.

Rohani, A. R. (2017) A survey of the big five personality traits among elementary teachers [Master's thesis, Online], Available: http:// stars.library.ucf.edu/honorstheses/257 [20 May 2019]

Rosenthal, S. A. and Pittinsky, T. L. (2006) 'Narcissistic leadership', The leadership quarterly, Vol. 17, No. 6, pp. 617-633. https:/ doi.org/10.1016/j.leaqua.2006.10.005

Rothmann, S. and Storm, K. (2003) 'The relationship between burnout, personality traits and coping strategies in a corporate pharmaceutical group', SA Journal of Industrial Psychology, Vol 29, No. 4, pp. 35-42. https://doi.org/10.4102/sajip.v29i4.128

Sears, S. F., Urizar, G.G. and Evans, G.D. (2000) 'Examining a stresscping model of burnout and depression in extension agents', Journal of Occupational Health Psychology, Vol. 5, No. 1, pp. 56-62. https://doi.org/10.1037/1076-8998.5.1.56

Selingson, A.G. (1992) 'The narcissistic therapist meets a narcissistic patient', Journal of Contemporary Psychotherapy, Vol. 22, No. 3, pp. 221-221. https://doi.org/10.1007/BF00945987
Schwarzkopf, K., Straus, D., Porschke, H., Znoj, H., Conrad, N., Schmidt-Trucksäss, A. and Von Känel, R. (2016) 'Empirical evidence for a relationship between narcissistic personality traits and job burnout', Burnout Research, Vol. 3, No. 2, pp. 25-33. https://doi.org/10.1016/j.burn.2015.12.001

Skaalvik, E. M. and Skaalvik, S. (2010) 'Teacher self-efficacy and teacher burnout: A study of relations', Teaching and teacher education, Vol. 26, No. 4, pp. 1059-1069. https://doi. org/10.1016/j.tate.2009.11.001

Tamban, V. E. and Banasihan, G. L. (2017) 'Big Five Personality Traits And Teaching Performance Of Faculty Of College Of Teacher Education, Laguna State Polytechnic University', International Journal of Research - GRANTHAALAYAH, Vol. 5, No. 9, pp. 99-105. https://doi.org/10.29121/granthaalayah.v5.i9.2017.2209

Tan, S., Mansi, A. and Furnham, A. (2018) 'Students' preferences for lecturers' personalities', Journal of Further and Higher Education, Vol. 42, No. 3, pp. 429-438. https://doi.org/10.1080/ $\underline{0309877 X .2017 .1301406}$

Travers, C. J. and Cooper, C. L. (1993) 'Mental health, job satisfaction and occupational stress among UK teachers', Work \& Stress, Vol. 7, No. 3, pp. 203-219. https://doi. org/10.1080/02678379308257062

Van Horn, J. E., Schaufeli, W. B. and Enzmann, D. (1999) 'Teacher burnout and lack of reciprocity', Journal of Applied Social Psychology, Vol. 29, No. 1, pp. 91-108. https://doi. org/10.1111/j.1559-1816.1999.tb01376.x

Vavricová, M. (2013) 'Súčasné trendy vo výskume zvládania stresu', Československá Psychologie, Vol. 57. No. 2, pp. 134-143. 